\title{
PERALIHAN HAK ATAS TANAH ABSENTE KARENA WARIS (STUDI KASUS DI KANTOR ATR/BPN KABUPATEN KENDAL YANG DOMISILI AHLI WARIS BERADA DILUAR WILAYAH KECAMATAN )
}

\author{
Ika Rahma Wanti ${ }^{*}$, Munsyarif Abdul Chalim ${ }^{* *}$ \\ * Mahasiswa Program Magister (S2) Kenotariatan Fakultas Hukum UNISSULA, Semarang, e-mail: \\ ikarahmawanti89@gmail.com \\ ** Dosen Fakultas Hukum UNISSULA, Semarang
}

\section{ABSTRACT}

The law states that if a person has an excess of absent land then the land must be released or the sanction will be imposed. In fact, although this prohibition applies, the ownership or control of agricultural land in absente or drags is found in many sub-districts in kendal district, in the kendal district, there are many owners of agricultural land owned by persons or legal entities that are not only outside the kecamatan but sometimes Outside areas such as, Semarang city, and even those who are domiciled outside the province.

The problems studied in this study are as follows: (1) how the concept of transition of absente land rights due to the heirs whose domicile heirs are outside the district area, (2) how the legal protection for the heirs of absente land owners who live outside District area.

This study uses empirical juridical approach, empirical juridical approach in this research means that in analyzing the problem is done by combining legal materials (which is secondary data) with primary data obtained in the field.

The results of this study indicate the following: (1) The ownership of Asbsentee land rights due to inheritance issues the right to the heirs to obtain the rights to the absentee land, and for the transition of absentee land to legal certainty, (2) Protection for the heirs of land owners Absentees residing outside the sub-district may occur if the inheritance has been in accordance with the legislation in the true sense of being the heir of the absentee landowner and the heirs residing outside the sub-district work on their own farmland.

Keywords: Absente Land / Guntai, Heirs, Land Rights Transfer.

\section{PENDAHULUAN}

UU Pokok Agraria (UU Nomor 5 Tahun1960) merupakan salah satu hukum prodak nasional yang memiliki dua makna dalam tema penataan reformasi agraria, yakni (i) tidak berlakunya lagi hukum agraria kolonial,dan (ii) tonggak atas pembangunan hukum agraria nasional. Undang-undang Pokok agraria Nomor 5 Tahun 1960 atau yang familar disebut UUPA ini, juga merupakan undangundang yang memberlakukan reformasi agraria dengan ditandai adanya panca program reforma agraria Indonesia, terutama program ketiga yakni tentang perombakan pemilikan dan penguasaan atas tanah serta hubungan hukum yang berkaitan dengan penguasaan tanah dalam mewujudkan pemerataan kemakmuran dan keadilan, yang dikenal sebagai landreform.

Keterkaitan UUPA dengan landreform tergambarkan jelas pada muatannya, mulai dari menimbang hingga penjelasan UUPA, pasal 1 sampai pasal 19 maupun ketentuan konversi. ${ }^{1}$ Secara umum, materi UUPA yang sangat erat terkait landreform adalah Apasal 7 yang membatasi pemilikan dan penguasaan tanah,

1 P Parlindungan, Landreform Indonesia Suatu Perbandingan, Alumni, ABandung, 1987, hal. 14. 
pasal 10 yang mengatur tanah pertanian wajib dikerjakan sendiri secara aktif, dan pasal 17 menetapkan batas maksimum luas pemilikan tanah.

Pasal 10 Undang-Undang No. 5 ATahun 1960 Tentang Peraturan Dasar Pokok-Pokok Agraria yang dikenal dengan Undang-Undang Pokok agraria (UUPA) disebutkan

"Setiap orang dan badan hukum yang mempunyai sesuatu hak atas tanah pertanian pada asasnya diwajibkan mengerjakan atau mengusahakan sendiri secara aktif, dengan mencegah cara-cara pemerasan".2

Secara prinsip pasal ini menghendaki pemilik tanah pertanian untuk mengerjakan atau mengusahakan sendiri tanahnya dan masih diperbolehkan menggunakan tenaga buruh tetapi harus dicegah praktek yang dapat menimbulkan kerugian sepihak. Langkah pertama ke arah pelaksanaan asas tersebut, berarti bahwa pemilik tanah pertanian wajib mengerjakan atau mengusahakannya sendiri secara aktif, maka diadakanlah ketentuan untuk menghapuskan penguasaan tanah pertanian secara absentee atau dalam bahasa sunda dikenal dengan sebutan guntai ${ }^{3}$

Peraturan pelaksanaan dari UUPA yang mengatur mengenai pemilikan tanah secara absentee diatur dalam Pasal 3 ayat (1) PP No. 224 tahun 1961 tentang Pelaksanaan Pembagian Tanah dan Pemberian Ganti

\footnotetext{
${ }^{2}$ Di dalam Landreform Internasional istilah ini disebut absenteeisme. Lihat Boedi Harsono, Hukum Agraria Indonesia; Sejarah, Pembentukan Undang-Undang Pokok Agraria Isi dan Pelaksanaannya, Djambatan, Jakarta, 1999, hal.16.

${ }^{3}$ Salah satu aspek hukum penting dengan diundangkannya UUPA adalah dicanangkannya program / andreform yang bertujuan untuk mempertinggi penghasilan dan araf hidup para petani penggarap anah, sebagai andasan atau prasyarat untuk menyelenggarakan pembangunan ekonomi menuju masyarakat yang adil makmur berdasarkan Pancasila. dan ASalah Asatu dari program Alandreform Aadalah pelarangan Apemilikan Atanah Asecara absentee untai, yang berpangkal pada dasar hukum Pasal 10 UUPA. Lihat Perangin, Hukum Agraria di Indonesia, Suatu Telaah dari Sudut andang Praktisi Hukum, Jakarta, CV. Rajawali, 1986 hal. 122.
}

Kerugian (telah diubah dan ditambah dengan PP No. 41 tahun 1964), menyebutkan:

pemilik tanah yang bertempat tinggal diluar kecamatan tempat letak tanahnya, dalam jangka waktu 6 bulan wajib mengalihkan hak atas tanahnya kepada orang ain di kecamatan tempat letak tanah itu atau pindah ke kecamatan letak tanah tersebut. ${ }^{4}$

Peraturan tersebut menunjukkan bahwa pemilikan tanah secara absente tidak diperbolehkan dan melanggar asas. Larangan untuk memiliki tanah secara absentee ini bertujuan supaya tanah pertanian yang berada di kecamatan tersebut dikelola sendiri oleh petani yang berada di kecamatan letak tanah itu sehingga, hasilnya pun dapat maksimal. Dan jika dibiarkan seseorang atau badan hukum memiliki tanah secara absentee akan menyebabkan ketidakadilan karena yang bekerja bukan pemilik tanah pertanian tersebut. Inti pokok dari pengaturan seperti ini adalah larangan kepemilikan tanah Apertanian Aoleh orang atau badan hukum yang bertempat tinggal diluar kecamatan tempat etak tanahnya berada. Akan tetapi larangan tersebut tidak berlaku terhadap pemilik yang bertempat tinggal di kecamatan yang berbatasan dengan

kecamatan tempat letak tanah yang bersangkutan, asalkan jarak antara tempat tinggal pemilik itu dan tanahnya menurut pertimbangan pada waktu itu masih memungkinkan untuk mengerjakan tanahnya secara efisien.

Dalam undang-undang itu dijelaskan bahwa seseorang apabila didapat menguasai tanah (absentee) maka tanah tersebut harus dilepaskan atau sanksi yang akan dikenakan jika kewajiban diatas tidak dilaksanakan atau bersangkutan akan diambil oleh pemerintah untuk kemudian didistribisikan dalam rangka landreform. Dan kepadaAbekas pemiliknya diberikan ganti. Akan tetapi, bagi pemilik tanah dapat menyelamatkan hak kepemilikannya dari diambilnya oleh pemerintah antara lain dengan Acara:

\footnotetext{
${ }^{4}$ Urip Santoso, Hukum Agraria dan Hak-Hak Atas Tanah, Prenada Media Group, Jakarta, 2005, hal. 57.
} 
1. Tanah tersebut dijual kepada masyarakat disekitar lokasi kecamatan tersebut

2. Ditukarkan kepada penduduk setempat (yang Aberada diwilayah tempat tanah berada)

3. Salah satu anggota keluarganya pindah tempat tinggal disekitar tanah itu berada

4. Diberikan sukarela kepada penduduk setempat (biasanya berupa wakaf atau hibah)

Faktanya, walaupun larangan ini masih berlaku sampai dengan hari ini, kepemilikan dan atau penguasaan tanah pertanian secara absenteeternyata banyak dijumpai di berbagai kecamatan di Kabupaten Kendal. Di Kabupaten saat ini banyak kepemilikan tanah pertanian banyak yang dimiliki oleh orang atau badan hukum yang bukan saja berada di luar kecamatan, namun kadang luar daerah seperti Kota Semarang dan bahkan ada pula yang berdomisili atau berpenduduk luar propinsi dan nampaknya menjadi trend belakangan ini. Hal ini tidak mengherankan, karena Kabupaten Kendal sebagai wilayah penopang Kota Semarang akhirakhir ini nampaknya menjadi destinasi bagi kalangan pengusaha untuk menempatkan perusahaan, gudang dan pertokoan, sehingga banyak lahan pertanian yang beralih fungsi menjadi sentra industri.

Artinya, pemilik tanah pertanian secara absentee bukanlah para petani tetapi orangorang kota yang bukan merupakan penduduk setempat, yang mendapatkan tanah tersebut melalui jual beli, pewarisan atau cara-cara lainnya, dan penggunaan tanah itu bukan untuk diolah sebagaimana peruntukkan tanahnya, namun hanya sebagai sarana investasi dan nantinya dijual kembali setelah memiliki nilai jual melangit. Tanah pertanian masih tetap dijadikan obyek spekulasi yang mengakibatkan luas tanah pertanian semakin berkurang karena dialih fungsikan.

Alih fungsi lahan seperti ini kalau hanya melihat dalam perspektif ekonomi tentunya bukanlah problem, namun apabila dilihat dalam

kapasitasnya dalam penegakan hukum pertanahan di Indonesia pastinya ini adalah bagian daripada persoalan yang cukup serius, paling tidak mengancam tujuan daripada reformasi agraria. ${ }^{5}$ Belum I agi apabila mengacu pada pasal 10 UUPA tersebut diatas, dimana ada larangan untuk memiliki tanah secara absentee atau guntai maka persoalan akan menjadi kian komplek.

Berdasarkan uraian latar belakang di atas, maka dapatlah permasalahan sebagai dirumuskan beberapa berikut

Bagaimana konsep peralihan hak atas tanah absentee karena yang domisili ahli warisnya berada di luar wilayah kecamatan? Bagaimana perlindungan hukum bagi ahli waris pemilik hak atas tanah absentee yang bertempat tinggal di luar kecamatan?

\section{METODE PENULISAN}

Metode penulisan merupakan hal yang penting dalam kegiatan penelitian, untuk mendapatkan data kemudian menyusun, mengolah, dan menganalisisnya. Dalam kaitan ini jenis penelitian yang digunakan adalah penelitian hukum empiris. Penelitian hukum empiris merupakan penelitian yang pada awalnya meneliti tentang data sekunder untuk kemudian dilanjutkan dengan penelitian terhadap data primer di lapangan. Ciri utama penelitian hukum empiris ini adalah suatu penelitian yang beranjak dari adanya kesenjangan antar das sollen dengan $d$ as sein yaitu kesenjangan antara teori dan dunia realita. Adapun spesifikasi penelitian ini masuk dalam kategorisasi penelitian yang dilaksanakan dalam penelitian deskriptif. $^{6}$ Sifat

${ }^{5}$ Menurut Fauzi terdapat 4 (empat) tipe andreform berdasarkan aktor utama Penggeraknya, yaitu, (i) Market-Led Landreform, (ii) State-Led Landreform,

(iii) Peasant-Led Landreform, dan (iv) Pro-Poor Landreform. Lihat Noer Fauzi, Bersaksi Untuk Pembaharuan Agraria, Insist Press, Yogyakarta, 2003, Hal.

6 deskriptif, yang bertujuan untuk menggambarkan secara tepat sifat-sifat individu, keadaan, gejala atau suatu kelompok menentukan ada tidaknya hubungan antara suatu gejala lainnya dalam 
penelitian deskriptif maksudnya adalah penelitian yang dimaksudkan untuk memberikan data yang seteliti mungkin terkait dengan manusia suatu keadaan dan gejala-gejala lainnya.

Metode pengumpulan data dalam penelitian ini dilakukan dengan observasi (pengamatan), nterview (wawancara), kuesioner (angket) dan dokumentasi. dapun teknik analisa yang digunakan ialah metode deskriptif kualitatif. Di dalam penelitian ini, alat Apengumpulan data Ayang dipergunakan mencakup studi kepustakaan serta wawancara (interview), studi pustaka,dan observasi lapangan. Untuk mendapatkan hasil yang semaksimal mungkin, ketiga jenis alat pengumpulan akan di gabungkan, dimana masing-masing akan menguatkan yang lainnya. Pengamatan atau observasi digunakan untuk mencatat atau mendeskripsikan perilaku (hukum) yang terjadi di masyarakat, adapun wawancara dilakukan dengan memperoleh data mengenai persepsi responden yang memiliki keahlian dan atau mereka yang terkait dengan objek.

\section{PEMBAHASAN}

$\begin{array}{lcllr}\text { Konsep } & \text { Peralihan hak atas tanah } \\ \text { absente } & \text { karena } & \text { yang domisili ahli } \\ \text { warisnya } & \text { berada } & \text { di luar wilayah } \\ \text { kecamatan } & & & & \end{array}$

Kata absentee berasal dari kata latin "absentee"atau "absentis", yang berarti tidak hadir. Dalam kamus Bahasa Inggris karangan John M. AEchlos dan Hasan Sadily, kata absenteediartikan sebagai yang tidak ada atau tidak hadir di tempatnya, atau disebut juga dengan istilah landlord, yaitu pemilik tanah

masyarakat. Dalam penelitian ini teori-teori, ketentuan peraturan, norma-norma hukum, karya tulis yang dimuat, baik dalam literatur maupun jurnal, doktrin serta laporan penelitian terdahulu sudah mulai ada, bahkan jumlahnya cukup memadai, sehingga dalam penelitian ini hipotesis tidak mutlak harus diperlukan, atau dengan kata lain hipotesis boleh ada boleh tidak. Lihat. mirudin dan Zainal sikin, Pengantar Metode Penelitian Hukum, Raja rafindo Persada, 2010 Jakarta, hal. 25 bukan penduduk daerah itu, tuan tanah yang bertempat $t$ inggal di lain tempat. ${ }^{7}$

Pemilikan tanah pertanian secara

absentee atau di dalam bahasa Sunda "guntai" memiliki pengertian, pemilikan tanah pertanian yang letaknya di luar tempat tinggal yang mpunya. Sedangkan dalam Pasal 3 ayat (1) PP No 224 Tahun 1961 tentang Pelaksanaan Pembagian Tanah dan Pemberian Ganti Kerugian (telah diubah dan ditambah dengan PP No. 41 Tahun 1964) yang disebutkan sebagai berikut:

"pemilik tanah pertanian yang bertempat tinggal di luar kecamatan tempat letak tanahnya, dalam jangka waktu 6 bulan wajib mengalihkan hak atas anahnya kepada orang lain di kecamatan tempat etak tanah itu atau pindah ke kecamatan letak tanah tersebut".

Dari penjelasan ini menunjukkanA bahwa pemilikanAtanah pertaniaA secara absente menurut Peraturan Perundang-undangan idak diperbolehkan, karena pada prinsipnya melanggar asas dalam Pasal 10 UUPA yang mengatur bahwa setiap orang dan badan hukum yang mempunyai sesuatu hak atas tanah pertanian pada asasnya diwajibkan mengerjakan atau mengusahakannya sendiri secara aktif, dengan mencegah cara-cara pemerasan.

\section{Pada umumnya}

tanah-tanah

pertanian letaknya adalah di desa sedang mereka yang memiliki tanah secara absentee umumnya bertempat tinggal di kota. Orang yang tinggal di kota memiliki tanah pertanian di desa tentunya tidak sejalan dengan prinsip tanah pertanian untuk petani. Orang yang tinggal di kota sudah jelas bukan bukan termasuk kategori petani. Tujuan melarang pemilikan tanah pertanian secara absentee/guntai adalah agar hasil yang dip petani yang tinggal di pedesaan, bukan dinikmati oleh orang kota yang tidak tinggal di desa.

\footnotetext{
${ }^{7}$ John M. Echols dan Hasan Sadily, Kamus InggrisIndonesia, Gramedia, Jakarta, 1996, hal. 3

${ }^{8}$ Effendi Perangin, Op.cit, hal. 122.
} 
Pemilikan tanah pertanian secara absentee ini mengakibatkan tingginya biaya produksi pertanian, misalnya tentang penyelenggaraannya, pengawasannya, pengangkutan hasil pertanian, juga dapat menimbulkan sistemsistem penghisapan. Ini berarti bahwa para petani penggarap tanah milik orang lain dengan sepenuh tenaganya, tanggung jawabnya dan segala resikonya, tetapi hanya menerima sebagian dari hasil yang dikelolanya. $\mathrm{Di}$ sisiAlain, pemilik tanah yang berada jauh dari letak tanah dan tidak mengerjakan tanahnya tanpa menanggung segala resiko dan tanpa mengeluarkan keringatnya akan mendapatkan bagian lebih besar dari hasil tanahnya.

Dengan demikian hal ini tidak sesuai dengan tujuan dari reformasi agraria yang diselenggarakan di Indonesia yaitu untuk mempertinggi penghasilan dan taraf hidup para petani penggarap tanah dan sebagai landasan atau persyaratan untuk menyelenggarakan pembangunan ekonomi menuju masyarakat yang adil dan makmur berdasarkan Pancasila.

Secara yuridis, dasar hukum mengenai larangan pemilikan tanah pertanian secara absentee/guntai telah dituangkan dalam Pasal 3 PP No 224 Tahun 1961 dan PP No 41 Tahun 1964 (tambahan Pasal 3a s/d 3e). Kedua Peraturan Pemerintah ini merupakan aturan pelaksanaan dari ketentuan yang tertuang dalam Pasal 10 UUPA, yang bertujuan untuk mencegah terjadinya sistem pemerasan yang dilakukan terhadap golongan ekonomi lemah.

Dalam Pasal 10 UUPA telah dikemukakan bahwa yang mempunyai tanah pertanian wajib mengerjakan atau mengusahakannya sendiriAsecara aktif, sehingga kemudian diadakanlah ketentuan untuk menghapuskan penguasaan tanah pertanian secara apa yang disebut absentee/guntai yaitu pemilikan tanah yang letaknya di luar wilayah kecamatan tempat tinggal pemilik tanah.
Pada pokoknya dilarang memiliki tanah di luar kecamatan tempat letaknya tanahnya. Larangan tersebut tidak berlaku terhadap pemilik yang bertempat tinggal di kecamatan yang berbatasan dengan kecamatan tempat letak tanah yang bersangkutan, asal jarak tempat pemilik itu dan tanahnya, masih memungkinkannya untuk mengerjakan tanah tersebut secara efisien. Mengingat bahwa tujuan ketentuan Pasal 10 UUP Aini adalah menyangkut kepentingan umum, maka secara yuridis ketentuan dalam pasal ini termasuk ketentuan-ketentuan hukum yang memaksa atau " dwingend recht".

JangkaAwaktu pemindahan hakAmilik atas tanah pertanianAyang dimaksud dalam pasal tersebutAperlu dibatasi agarApemilik tanahAyang bersangkutanAtidak mengulur-ulur waktuAdalam usahanya untukAmemindahkanAhak miliknya tersebut. Jika kewajibanAtersebut tidakAdilaksanakan atau terjadiApelanggaran terhadap laranganAtersebut maka tanah yangAbersangkutan akan diambil alih oleh Pemerintah untuk kemudahan diredistribusikan dalamArangka program landreform, danAkepada bekas pemilik diberikanAganti rugi menurut ketentuan yang berlaku.APemberian ganti rugi ini diaturAdalam Pasal 6 danAPasal 7 PP. 224 Tahun 1961.

Jadi siapapun dalam hubungan dengan masalah pemilikan tanah absentee/guntai harus tunduk kepada Peraturan Pemerintah tersebut. Selain daripada itu dalam Pasal 19 Peraturan Pemerintah No 224 Tahun 1961 ditetapkanAsanksi pidana kepadaApemilik tanah yangAmenolak atau dengan sengajaAmenghalanghalangi pengambilanAtanah olehApemerintah dan pembagiannya.

Yang terjadiAdalam praktik adalahAbahwa ada sebidangAtanah pertanian yang dimiliki olehAseseorang dalamAkenyataannya sudahAtidak dikuasainyaAlagi karena telahAberalih secara diamdiamAke tangan orangAlain yang berdomisili diluarAkecamatan letak tanahAtersebut. 
PenguasaanAtanah secaraAabsenteeini pada umumnyaAdiketahui olehAmasyarakatAsekitar. ${ }^{9}$

Hal itu dapat terjadi melalui dua cara, yakni dengan cara memiliki KTP ganda yang memungkinkan seseorang menyelundupi ketentuan tentang tanah absent edan melalui upaya pemindahan hak terselubung yang dikenal dengan cara pemberian kuasa mutlak. Melalui kuasa mutlak, maka pemberi kuasa (sebenarnya penjual) memberikan kuasa yang tidak dapat ditarik kembali kepada penerima kuasa (sebenarnya pembeli) yang diberi wewenang untuk menguasai, menggunakan, dan melakukan segala perbuatan hukum pemindahan hak atas tanah yang menjadi obyek pemberian Akuasa, sehingga pada hakekatnya merupakan perbuatan hukum pemindahan hakA atas tanah. Hal ini jelas merupakan penyelundupan hukum, karena dimaksudkan untuk melanggar ketentuan peraturan perundang -undangan.

Gejala yang tampak adalah bahwa di satu pihak pemilik semula yang menggantungkan hidupnya pada produk pertanian justru terdepak dari tanahnya karena kebutuhan akan uang, dan di pihak lain ada orang yang mempunyai kelebihan modal yang menginginkan penumpukan tanah sebagai sarana investasi. Maka yang terjadi adalah gejala menjadi buruh di atas tanah "miliknya" sendiri.

Sebagaimana telah dijelaskan di atas, bahwa meskipun pemilikan tanah perta pengamatan penulis di lapangan, banyakA dijumpai adanyaA pemilikan tanah pertanian secara absentee KabupatenA Kendal di Kecamatan Brangsong, Weleri Maupun Kota Kendal sendiri. Hal ini dapat ditunjukkan pada bukti tempat tinggal atau domisili pemilik tersebut adalah di luar kecamatan tetapi pada kenyataannya memiliki tanah pertanian di kecamatan tersebut. Berdasarkan data yang penulis peroleh dari Kecamatan Brangsong, dapat diperolehAdata atas pemilikan tanahAabsentee/guntaiAsebagai berikut :

\section{Pemilikan Tanah Absente di Kabupaten $K$ endal}

\footnotetext{
${ }^{9}$ Maria S.W. Sumardjono, Kebijakan Pertanahan, Antara Regulasi dan Implementasi, Penerbit Buku Kompas, Jakarta, 2005, hal. 21.
}

\begin{tabular}{|l|c|c|}
\hline Kecamatan & $\begin{array}{l}\text { Pemilik } \\
\text { tanah }\end{array}$ & $\begin{array}{r}\text { Luas } \\
\text { tanah }\end{array}$ \\
\hline Brangsong & 36 & $41 \mathrm{Ha}$ \\
\hline $\begin{array}{l}\text { Kota } \\
\text { Kendal }\end{array}$ & 28 & $17 \mathrm{Ha}$ \\
\hline Weleri & 42 & $52 \mathrm{Ha}$ \\
\hline
\end{tabular}

\section{Perlindungan hukum bagi ahli waris pemilik hak atas tanah absentee yang bertempat tinggal di luar kecamatan}

Dalam konsep hukum, hubungan antara orang dengan benda merupakan hubungan yang disebut dengan hak. MaknaAdari sebutan itu adalah hak kepemilikan atas suatu benda, disebut hak milik atas benda itu, atau dikenal sebagai property right. Dalam konsep hukum, hak dapat dibedakan menjadi hak perorangan dan hak kebendaan. Sedangkan benda dalam konsep hukum, tidak hanya dapat berupa bendaAberwujud nyata seperti mobil dan rumah yang disebut Atangible things, tetapi jugaAbenda lainnya Ayang tidak Aberwujud seperti hak paten, hak cipta, dan Asebagainya yang disebut intangible things. Lebih lanjut dikemukakan, bahwa milik atau kepemilikan Abukan hanya sekedar hubungan antara sAeseorang atau Badan AHukum yang Adisebut subyek hukum dengan benda yang secara hukum dapat dikuasai, tetapi bagi subyek hukum Ayang bersangkutan memiliki Akonsekuensi adanya Ahak yang disebut Asebagai kepemilikan atas benda tersebut.

MenurutA Satjipto Rahardjo, pemilikan mempunyai sosok hukum yang lebih jelas dan pasti, dibanding dengan penguasaan. Pemilikan menunjukkan hubungan antara seseorang dengan obyek yang menjadi sasara $n$ pemilikan. Namun berbeda dengan penguasaan yang lebih bersifat faktual, maka pemilikan terdiri dari suatu kompleks hak-hak, yang kesemuanya dapat digolongkan ke dalam ius in rem, karena pemilikan berlaku terhadap semua orang. Hal ini berbeda dengan ius personam yang hanya berlaku erhadap orang-orang tertentu. 
Dengan mengutip pendapat Fitzgerald, Satjipto Rahardjo memaparkan ciri-ciri dari hakhak yang termasuk pemilikan, sebagai berikut:

(1)Pemilik mempunyai hak untuk memiliki barangnya. Ia mungkin tidak memegang atau menguasai barang tersebut, Aoleh karena Abarang itu mungkin telah direbut dari padanya oleh orang lain. Sekalipun demikian, hak atas barang itu tetap ada pada pemegang hak semula;

(2)Pemilik biasanya mempunyai hak untuk menggunakan dan menikmati barang yang dimilikinya, yang pada dasarnya merupakan kemerdekaan bagi pemilik untuk berbuat Aterhadap barangnya;

(3) Pemilik mempunyai hak untuk menghabiskan, merusak atau mengalihkan barangnya. ada Aorang yang menguasai suatu barang, hak untuk mengalihkan itu tidak ada padanya karena adanya asas memo dat quod nonhabet. $\mathrm{Si}$ penguasa tidak mempunyai hak dan karenanya juga tidak dapat melakukan pengalihan hak kepada orang lain;

(4)Pemilikan mempunyai ciri tidak mengenal jangka waktu. Ciri ini sekali lagi membedakan pemilikan dengan penguasaan, oleh karena yang disebut terakhir, terbuka untuk penentuan statusnya lebih lanjut di kemudian hari. Pemilikan secara teoritis berlaku selamanya.

(5)Pemilikan mempunyai ciri yang bersifat sisa. Seorang pemilik tanah bisa menyewakan tanahnya kepada, memberikan hak untuk melintasi tanahnya kepada B dan kepada C memberikan hak yang lain lagi, sedang ia tetap memiliki hak atas tanah itu yang terdiri dari sisanya sesudah hak-hak itu ia berikan kepada mereka itu. Dibandingkan dengan pemilik hak untuk melintasi tanah itu, maka hak dari pemilik Abersifat tidak terbatas. Kita akan Amengatakan, Abahwa hak yang pertama bersifat menumpang pada hak pemilik yang asli dan keadaan i ni disebut sebagai in re linea.

Serupa dengan pendapat tersebut di atas, menurut Lili Rasjidi, Hak Milik adalah hubungan Aantara seseorang dengan Asuatu bendaA yang membentuk hak pemilikan terhadap Abenda tersebut. Hak ini merupakan suatu himpunan hak-hak yang kesemuanya merupakan hak-hak in rem, yang terdiri dari:

1) Hak Milik untuk sesuatu. Pemilik berhak untuk memiliki benda yang dimilikinya. Benda ini barangkali telah dicuri, diberikan kepada seseorang untuk sementara Waktu atas dasar pinjaman, digadaikan, dan lainlain. Bagaimanapun, pemilik dapat menguasai kembali bendanya dalam hal hubungan tersebut di atas telah selesai. Dalam beberapa kasus tertentu, pemilik dapat mengajukan tuntutan atau gugatan untuk mengembalikan barang miliknya;

2) Hak untuk menggunakan dan menikmati. Pada dasarnya pemilik dapat menggunakan dan menikmati barang Amiliknya sesuka hati;

3) Hak untuk memakai, mengasingkan, bahkan membinasakan;

4) Waktu yang tak terbatas. Pemilikan i ni tak terbatas waktunya;

5) Pemilikan mempunyai sifat sisa. Bahwa walaupun hak penguasaan telah diserahkan kepada pihak lain karena kontrak sewa misalnya, maka hak-hak yang tersisa terhadap benda tersebut tetap melekat pada pemilik.

Pemilikan mempunyai arti Atersendiri, dalam Ahubungannya Adengan kehidupan masyarakat tempat ia diterima sebagai suatu konsep hukum. Dalam artinya yang demikian itu, pemilikan dibicarakan dalam konteks sosial, dan bukan dalam kategori yuridis. Dalam konteks sosial, pemilikan bisa merupakan indeks, tidak hanya bagi tingkat kesejahteraan dari pemiliknya, tetapi juga bagi kedudukan sosialnya.

Fungsi sosial pemilikan juga terlihat dalam hubungannya dengan penggunaannya untuk menyampaikan ide-ide politik Adan sosial pada ASebuah Kajian Normatif untuk Keadilan bagi Masyarakat Azamannya. Dengan Ademikian, pemilikan lalu Amenjadi lambang dari Akemenangan atau dominasi pemikiran sosial dan politi pada suatu saat. Pada suatu saat pemilikan dapat Abersifat sangat individualistis, 
dan pada saat yang lain bisa berubah menjadi konsep yang Abersifat sosialis, dan sebagainya.

Dalam hubungannya dengan Hak Milik atas tanah, maka ada satu proses yang harus dilalui, yaitu proses penguasaan. Proses itu dalam Hukum Barat dikenal sebagai possession, yang berbeda makna Adengan ownership. Syarat lain bagi possession Aadalah adanya niat atau adanya maksud untuk memiliki dengan itikad baik. Niat untuk memiliki dikaitkan dengan waktu dan bukti lainnya. Maka dengan demikian, Ahak menguasai itu harus didahului dengan tindakan pendudukan/menduduki untuk memperoleh penguasaan itu, dan dengan batas waktu tertentu akan menjadi hak milik.

Chambers mengemukakan bahwa; "to have possession Aof a thing, a person must control that thing an intend to posses it. Both are required". Dengan demikian yang dimaksud dengan possession adalah $\mathrm{p}$ enguasaan fisik melalui pendudukan dan disertai dengan adanya niat untuk memiliki. Hal itu akan lebih jelas apabila dibandingkan dengan pengertianA ownership. Pengertian ownership dalam bahasa Indonesia dapat diartikan sebagai kepunyaan atau kepemilikan atas suatu benda. Ownership termasuk di dalamnya hak untuk menguasai bendanya secara nyata, atau seseorang yang mempunyai suatu benda, namun belum tentu menguasai secara fisik. Dalam hal benda tidak berwujud, maka seseorang menguasai bendanya namun tidak menguasai secara nyata. Misalnya hak paten dan hak cipta. Demikian pula halnya seseorang mempunyai benda berwujud, Anamun belum tentu orang yang dimaksud menguasai benda tersebut, misalnya menyewakan sebuah tanah atau rumah.

Secara tegas perbedaan possession dalam arti penguasaan fisik dengan ownership dalam arti kepunyaan atau kepemilikan adalah bahwa penguasaan melibatkan pendudukan secara fisik, adanya niat untuk menguasai, yang dapat diperoleh tanpa alas hak. Sedangkan pemilikan harus dibuktikan sebagai hak mutlak dan perpindahan pemilikan harus dilakukan dengan hak, tidak sekedar serah Aterima penguasaan. Oleh karena itu,Adapat dinilai bahwa penguasaan merupakan cikal bakal adanya pemilikan, sedangkan arti milik itu sendiriA melekat padaA adanya hak, sehingga Adibedakan adanya istilah private property untuk Amenunjukkan milik pribadi dan public property untuk menunjukkan milik negara atau milik umum.

Pendaftaran tanah untuk pertama kali adalah kegiatan pendaftaran yang dilakukan terhadapA objek pendaftaran Atanah yang belumA didaftar berdasarkan Peraturan APemerintah No. 10 Tahun 1961 dan APeraturan Pemerintah No. 24 Tahun 1997. Objek dari Apendaftaran tanah Auntuk Apertama kali adalah tanah negara Adan tanah bekas hak Amilik adat.

Kegiatan pendaftaran tanah untuk pertama kalinya meliputi:

a. Pengumpulan dan pengolahan data fisik;

b. Pengumpulan dan pengolahan data yuridis sefta pembukuan haknya;

c. Penerbitan seflifikat;

d. Penyimpanan daftar umum dan dokumen.

Pendaftaran tanah secara sporadik adalah kegiatan pendaftaran tanah untuk pertama kali mengenai satu atau beberapa objek pendaftaran tanah dalam wilayah atau bagian wilayah suatu desa/kelurahan secara individu atau massal. Pendaftaran tanah secara sporadik dilaksanakan atas permintaan pihak yang berkepentingan, yaitu pihak yang behak atas objek pendaftaran tanah yang bersangkutan atau kuasanya.

Dalam Pasal 23 Peraturan Pemerintah Nomor 24 ATahun 1997 tentang Pendaftaran Tanah (selanjutnya disingkat PP No. 24/1997), menetentukan bahwa untuk keperluan pendaftaran:

a. Hak atas tanah baru dibuktikan dengan :

1) penetapan pemberian hak dari Pejabat yang ber-wenang memberikan hak yang bersangkutan menurut ketentuan yang berlaku apabila pemberian hak tersebut berasal dari tanah Negara atau tanahA hak penge-lolaan;

2) asli akta PPAT yang memuat pemberian hak tersebut oleh pemegang hak milik kepada penerima hak yang bersangkutan apabila mengenaiA hak guna bangunan dan hak pakai atasA tanah hak milik; 
b. Hak pengelolaan dibuktikan dengan penetapan Apemberian hak pengelolaan oleh Pejabat yang Aberwenang;

c. Tanah Awakaf dAibuktikan dengan akta Aikrar wakaf;

d. Hak milik atas satuan rumah susun dibuktikan dengan akta pemisahan;

e. Pemberian hak tanggungan dibuktikan dengan akta pemberian Ahak tanggungan.

Dalam hal pemilihan bukti tertulis tersebut tidak lengkap, maka dapat dilakukan Adengan Aketerangan saksi dan/atau pernyataan Apemilik tanah Ayang dipercaya Akebenarannya menurut Apendapat judikasi/Kepala Kantor Pertanahan, demikian dijelaskan lebih lanjut dalam APenjelasan Pasal 24 ayat (1) PP No. 24/ 1997 tentang Pendaftaran Tanah.

Dalam Pasal 24 ayat (2) PP No. 24/1997 diatur pembukuan hak dalam hal tidak atau tidak lagi tersedia secara lengkap alat-alat pembuktian pemilikan yang tertulis, keterangan saksi ataupun pernyataan yang bersangkutan yang dapat dipercaya kebenarannya mengenai kepemilikan tanah yang bersangkutan, sebagaimana yang disebut dalam ayat (1) di atas. Dalam hal yang demikian, pembukuan haknya dapat dilakukan tidak didasarkan pada bukti pemilikan, melainkan pada bukti penguasaan fisik tanahnya oleh pemohon pendaftaran dan pendahuluan-pendahuluannya selama 20 tahun atau lebih secara berturut turut.

Dalam Penjelasan Pasal 24 ayat (2) PP No. 24/1997, dirinci syarat-syarat yang harus dipenuhi bagi pembukuan hak yang bersangkutan, yaitu:

a. Bahwa penguasaan dan penggunaan tanah yang bersangkutan dilakukan secara nyata dan dengan i tikad baik selama 20 tahun atau lebih secara Aberturut-turut;

b. Bahwa kenyataan penguasaan dan penggunaan tanah tersebut selama itu tidak diganggu gugat dan karena itu dianggap diakui dan dibenarkan oleh masyarakat hukum adat atau desa/kelurahan yang bersangkutan; c. Bahwa hal-hal tersebut diperkuat oleh kesaksian orang-orang yang dapat dipercaya;

d. Bahwa telah diberikan kesempatan kepada pihak lain untuk mengajukan keberatan melalui pengumuman Asebagaimana dimaksud Pasal 26;

e. Bahwa telah diadakan penelitian juga mengenai kebenaran hal-hal yang disebutkan di atas;

f. Bahwa akhirnya kesimpulan mengenai status tanah dan pemegang haknya ituangkan dalam keputusan berupa pengakuan hak yang bersangkutan oleh Panitia judikasi dalam pendaftaran tanah secara sistematik dan oleh AKepala Kantor Pertanahan Adalam pen-daftaran tanah secara sporadik.

Sertifikat sebagai surat tanda bukti hak, diterbitkan untuk kepentingan pemegang hak yang bersangkutan sesuai dengan data fisik yang ada dalam surat ukur dan data yuridis yang telah didafiar dalam buku tanah. Memperoleh sertifikat adalah hak pemegang hak atas tanah, yang dijamin undang-undang.

Penerbitan sertifikat dimaksudkan agar pemegang hak Adapat dengan mudah membuktikan haknya. Oleh karena itu, sertifikat merupakan alat pembuktian yang kuat, sebagaimana dinyatakan Adalam Pasal 19 UUPA. Sehubungan dengan itu apabila masih ada ketidakpastian mengenai hak atas tanah yang bersangkutan, yang tercatat dari masih adanya catatan dalam pembukuannya, pada prinsipnya sertifikat belum dapat diterbitkan. Namun apabila catatan itu hanya mengenai data fisik yang Abelum lengkap, tetapi tidak disengketakan, sertifikat dapat diterbitkan.

Pendaftaran peralihan hak karena pewarisan diwajibkan dalam rangka memberi perlindungan hukum kepada para ahli waris dan demi ketertiban tata usaha pendaftaran tanah, agar data yang tersimpan Adan Adisajikan selalu menunjukkan Akeadaan yang mutakhir. Berbeda dengan ketentuan APeraturan Pemerintah ANo. 10 Tahun 1961, tidak Aditetapkan jangka Waktu Adilakukan pendaftarannya. Sebaliknya, ada 
ketentuan dalam Pasal 61 Aayat (3) yang membebaskan pendaftaran peralihan haknya dari pembayaran biaya Apendaftaran, bilamana Adilakukan dalam waktu 6 bulan sejak tanggal meninggalnya pewaris

\section{PENUTUP}

\section{Kesimpulan}

Berdasarkan pada pembahasan diatas, maka dalam penulisan ini dapat disimpulkan bahwa:

a. Kepemilikan hak atas tanah absentee karena waris menerbitkan hak bagi ahli waris untuk memperoleh hak atas tanah absentee tersebut, dan agar peralihan Atanah absentee tersebut memperoleh kepastian hikum, maka hli waris tersebut membuat surat keterangan ahli waris yang dikuatkan oleh pejabat yang berwenang dan mengurus proses balik nama sertifikat Atanah di kantor Badan Pertanahan Nasional. Dengan demikian diketahui Atanah absentee dapat diwariskan kepada ahli waris.

b. Perlindungan hukum bagi ahli waris pemilik hak atas tanah absentee yang bertempat tinggal di luar kecamatan dapat terjadi apabila pewarisan telah sesuai dengan peraturan perundang-undangan, dalam artian benar-benar sebagai ahli waris dari pemilik tanah absentee dan ahli waris yang bertempat tinggal di luar kecamatan tersebut Amenggarap sendiri tanah pertaniannya, ' (Pasal 10 UUPA, setiap orang dan badan hukum yang Amempunyai sesuatu hak atas tanah pertanian pada asasnya diwajibkan mengerjakan atau mengusahakannya sendiri secara aktif, dengan mencegah cara-cara pemerasan adapun cara-cara pemerasan tersebut telah ditentukan dalam Pasal 53 UUPA yaitu hak gadai, hak usaha bagi hasil, hak menumpang, dan hak sewa tanah pertanian, dengan demikian apabila ahli waris dari pewaris yang memiliki Atanah absentee bertindak melakukan cara-cara pemerasan yang demikian maka ahli waris tersebut tidak mendapat perlindungan hukum).

\section{Saran}

Berdasarkan kesimpulan tersebut di Aatas, maka ada dua saran yang muncul sebagai usaha untuk melakukan perbaikan :

a. Perlu adanya peran aktif dari Kantor Badan Pertanahan Nasional untuk aktif melakukan Apendataan dan Amembantu pendaftaran atas kepmilikan tanah absentee sehingga tanah absentee tersebut dapat secara optimal digunakan.

b. Dalam melaksanakan program landform, pemerintah perlu secara aktif melaksanakan Undang-Undang omor 56 Prp Tahun 1960 tentang Penetapan Luas Tanah Pertanian, dan Undang-Undang Nomor 2 Tahun 1960 tentang Perjanjian Bagi Hasil sehingga tanah absentee dapat secara optimal digunakan untuk kesejahteraan seluruh masyarakat.

\section{DAFTAR PUSTAKA}

Amirudin dan Zainal Asikin. 2010. Pengantar Metode Penelitian Hukum. Jakarta: Raja Grafindo Persada .

P Parlindungan. 1987. Landreform Indonesia Suatu Perbandingan. Bandung: Alumni.

Boedi Harsono. 1999. Hukum Agraria ndonesia; $S$ ejarah, Pembentukan Undang-Undang Pokok Agraria Isi dan Pelaksanaannya. Jakarta: Djambatan.

Effendi Perangin. 1986. Hukum Agraria di Indonesia; Suatu elaah dari Sudut Pandang Praktisi Hukum. Jakarta: Rajawali.

Noer Fauzi. 2003. Bersaksi Untuk Pembaharuan graria. AYogyakarta: Insist Press.

Urip Santoso. 2005. Hukum Agraria dan HakHak Atas Tanah. Jakarta: Prenada Media Group.

John M. Echols dan Hasan Sadily. A1996. Kamus Inggris-Indonesia. Jakarta: Gramedia.

Maria SA.W. Sumardjono. 2005. Kebijakan Pertanahan; ntara Regulasi dan Implementasi. Jakarta: Penerbit Buku Kompas . 